\title{
Association between aflatoxin and aflatoxigenic fungi in Brazil nut (Bertholletia excelsa H.B.K.)
}

\author{
Associação de aflatoxinas e fungos aflatoxigênicos em castanha-do-Brasil (Bertholletia excelsa H.B.K.)
}

Ariane Mendonça PACHECO ${ }^{1 \star}$, Ana LUCAS ${ }^{1}$, Rosana PARENTE ${ }^{1}, \mathrm{Neuzimar} \mathrm{PACHECO}^{2}$

\begin{abstract}
Brazil nut has a high nutritional content and is a very important trade commodity to some Latin American countries. In order to evaluate its safety, 120 samples from different stages of the productive chain were analyzed in terms of: moisture content (mc), aflatoxigenic fungi and aflatoxin (LOQ = $1.95 \mu \mathrm{g} . \mathrm{kg}^{-1}$ total aflatoxin) using TLC. Among all samples, 4 (6.7\%) from the receiving area, and 5 (16.7\%), from retail presented aflatoxins above the LOQ, but the amount of aflatoxins was below the LOQ after the samples were dried in the plant. The positive samples were above the limit of total aflatoxin permitted by the European Union $\left(4.0 \mu \mathrm{g} \cdot \mathrm{kg}^{-1}\right)$ and Brazil $\left(30 \mu \mathrm{g} . \mathrm{kg}^{-1}\right)$. The mc mean was $22.43 \%$ in the receiving area, which is higher than that in the other stages samples. All the A. flavus strains were aflatoxigenic, and there was statistic association between the presence of aflatoxin and flavus strains. The aflatoxigenic fungi strains associated to the aflatoxins levels in the samples show that an effective control is necessary for the food safety in the Brazil nut production chain.

Keywords: Bertholletia; Aspergillus; moisture; chromatography.
\end{abstract}

\section{Resumo}

A castanha-do-Brasil tem um alto teor nutricional e é um importante produto comercial para alguns países da América Latina. Com objetivo de avaliar a segurança, 120 amostras de diferentes etapas da cadeia produtiva, foram analisadas quanto a: teor de umidade, fungos aflatoxigênicos e aflatoxinas (LOQ = 1,95 $\mu \mathrm{g} \cdot \mathrm{kg}^{-1}$ aflatoxinas totais) por CCD. Das amostras, 4 (6,7\%) da área de recepção, e 5 (16,7\%) do varejo apresentaram aflatoxinas acima do LOQ. Nas amostras após secagem na usina não foram detectadas aflatoxinas(<LOQ). As amostras positivas estavam acima dos limites aceitos pela União Européia $\left(4,0 \mu \mathrm{g} \cdot \mathrm{kg}^{-1}\right)$ e Brasil $\left(30 \mu \mathrm{g} . \mathrm{kg}^{-1}\right)$. A média do teor de umidade foi de $22,43 \%$ na etapa de recepção, maior do que as outras etapas estudadas. Todas as cepas de A. flavus eram aflatoxigênicas e houve associação estatística entre a presença de aflatoxinas e a presença da cepa de flavus. As cepas aflatoxigênicas associadas às aflatoxinas das amostras demonstram que é neccessario um controle efetivo da segurança alimentar na cadeia produtiva da castanha-do-Brasil

Palavras-chaves: Bertholletia; Aspergillus; umidade; cromatografia.

\section{Introduction}

Brazil nut (Bertholletia excelsa H.B.K.) grows in the Amazon region and represents a very important trade commodity to some Northern Brazilian States. After being harvested, the nuts are transported to the factories, where they can be kept in-shell or be shelled, or in other product forms (PACHECO; SCUSSEL, 2006). Due to the nutritional properties, Brazil nuts are well known for their source of oil, protein, and selenium (ANDRADE et al., 1999; CHANG et al., 1995; RYAN et al., 2006), but they have also been associated with the mycotoxin contamination (PACHECO; SCUSSEL, 2007). The aflatoxins are natural toxic contaminants from the mycotoxins group, secondary metabolites of fungi metabolism, associated with food and feeding. They are considered carcinogenic, capable of causing organic changes, and, in high concentrations, they are lethal to animals and humans (INTERNATIONAL AGENCY OF RESEARCH ON CANCER, 1997). They are mostly produced by Aspergillus, especially flavus and parasiticus, and these fungi grow in the rain forest conditions, high relative humidity $(\mathrm{rh})(>85 \%)$ and temperatures $\left(>25^{\circ} \mathrm{C}\right)$. The growth of each fungus is determined not only by environmental factors, but also by the relationship of the fungus and particular plants, or whether such a relationship does exist (PITT, 2006). In addition, the environmental conditions seem to directly influence the moisture content $(\mathrm{mc})$ and the food composition of tropical products, and they can promote the growth of fungi strains in such as Brazil nuts (ARRUS et al., 2005a). Some studies reported that aflatoxigenic strains, especially $A$. flavus, have been observed in in-shell and shelled Brazil nuts (CASTRILLON; PURCHIO, 1988; FREIRE; KOZAKIEWICZ; PATERSON, 2000; BAYMAN; BAKER; MAHONEY, 2002; ARRUS et al., 2005b).

In Brazil, the commercial trade of Brazil nuts involves great number of products exported every year. Nowadays, the

Recebido para publicação em 4/4/2008

Aceito para publicação em 4/1/2009 (003357)

Food Science Department, Pharmacy Faculty, University of Amazonas - UNAMA, R. Rio Itannana, 200, Cj Vieiralves, CEP 69053040, Manaus - AM, Brazil,

E-mail: arianepacheco@hotmail.com

${ }^{2}$ Nutricon Food Analysis, Manaus - AM, Brazil

${ }^{*}$ A quem a correspondência deve ser enviada 
Amazonas State is the most important producer, $3.200 .000 \mathrm{~km}^{2}$ of Brazil nut trees area, much larger than that in other countries such as Bolivia, $100.000 \mathrm{~km}^{2}$ (INSTITUTO BRASILEIRO DE GEOGRAFIA E ESTATÍSTICA, 2005). On the other hand, some factors have decreased the Brazil nut export, such as the restrictions of total aflatoxin amount $\left(4.0 \mu \mathrm{g} \cdot \mathrm{kg}^{-1}\right)$ imposed by the European Union (EU), since 1998 (EUROPEAN UNION, 1998a), the destruction of native trees, and the market competition with other nuts. Therefore, contamination of the Brazil nut by aflatoxin has been studied in previous researches, but the sampling method used in those studies was applied only for single stages of the chain and not for different harvest (STEINER et al., 1992; IOANNOU-KAKOURI et al., 1999; THUVANDER et al., 2001; CALDAS; SILVA; OLIVEIRA, 2002). In some of those studies, the number of samples was small and only a few positive samples were detected, and some other studies did not detect aflatoxins in Brazil nuts (KERSHAW, 1985; CANDLISH et al., 2001).

The surveillance in the Brazil nuts chain stages must be intense and continuous since the time of harvest, storage and transportation is about 15 to 30 days considering the processing time in the factory. During the nuts drying process, the moisture content decreases, but it is not clear if the temperatures of drying (around $60^{\circ} \mathrm{C}$ ) are enough to avoid the aflatoxin production. The evaluation could provide information to improve the effective control of aflatoxin contamination levels in Brazil nuts, increase the value of the commodity, and provide the native communities involved in the Brazil nut chain with income. This research was carried out during the period between 2003 and 2006 in order to evaluate the aflatoxigenic fungi and aflatoxins presence in Brazil nuts in three stages of the chain (receiving, after drying, and retail) in samples collected in the city of Manaus, Amazonas State, Brazil.

\section{Materials and methods}

\subsection{Materials}

a) Brazil nut: a total of 120 Brazil nut samples were collected in Manaus city, Amazonas State, Brazil, from 2003 to 2006. In each harvest, 30 samples were collected: in-shell $(n=10)$, shelled $(\mathrm{n}=10)$ and from retail stores $(\mathrm{n}=10)$;

b) Chemicals: aflatoxin standard solution: $B_{1}, B_{2}, G_{1}$, and $\mathrm{G}_{2}$, Sigma ${ }^{\circ}$; Toluene, Ammonium and acetonitrile (all Vetec $^{\circledR}$;

c) Culture media: bacteriological peptone, potato dextrose agar, and Malt agar (all Merck ${ }^{\circledR}$ ); and

d) Apparatus and Equipment: industrial mill (Caf $f^{\oplus}$; chromatovisor UV $366 \mathrm{~nm}\left(\mathrm{Tecnal}^{\circledR}\right)$, spectrophotometer $\left(\right.$ Femto $\left.^{\circledR}\right)$; moisture heater $\left(\right.$ Fanem $\left.^{\circledR}\right)$; bacteriological heater $\left(\right.$ Fanem $\left.^{\circ}\right)$, analytical balance (Gehaka $\left.{ }^{\oplus}\right)$; stereoscopic microscopy (Quimis ${ }^{\circledR}$ ); inox hygienized accessories to homogenization with capacity of $1 \mathrm{~kg}$; sterile plates $(90 \times 15)$.

\subsection{Methods}

a) Sampling: the samples were collected according to the European Union (1998b) method, the weight of the incremental sample of around $300 \mathrm{~g}$, and each lot was subdivided into sublots. According to this method, the number of incremental samples to be taken depends on the weight of the lot (lot weight in tonnes), with a minimum of 10 and a maximum of 100. In the case of lots in retail, the weight of the incremental sample depends on the weight of the retail packaging. Therefore, the samples were collected in a Brazil nut factory, located in Manaus, Amazonas (AM) State, Brazil, at different stages: (i) factory receiving $(\mathrm{n}=60)$, in-shell samples collected upon disembarking or immediately after disembarking; (ii) after factory drying $(\mathrm{n}=30)$, shelled samples collected at the vacuum packaging stage; (iii) retail $(n=30)$, shelled samples collected randomly from local markets in their original packaging. The samples were collected in a total of $30 \mathrm{~kg}$ each, milled in an industrial mill, and divided into portions of $10 \mathrm{~kg}$ for the analysis of aflatoxin, moisture content, $(\mathrm{mc})$ and mycological tests;

b) Aflatoxin: the analysis was carried out using the Association of Official Analytical Chemists (2005) method with thin layer chromatography (TLC). The detection limit (LOD) was measured as the lowest concentration detected as the fluorescence in the TLC method under UV light, with 365 $\mathrm{nm}$, and the LOQ, as the lowest point of the calibration curve with high repeatability. The values of LOD and LOQ for total aflatoxin were: 0.97 and $1.95 \mu \mathrm{g} . \mathrm{kg}^{-1}$, respectively. To each aflatoxin $\left(B_{1} ; B_{2} ; G_{1}\right.$, and $\left.G_{2}\right)$, the LOD and LOQ values were: $0.25,0.25,0.25$, and $0.22 ; 0.50,0.50,0.50$, and $0.45 \mu \mathrm{g} . \mathrm{kg}^{-1}$, respectively. To obtain the LOD and LOQ values, finely ground Brazil nuts were homogenized, and spiked prior to extraction with aflatoxins at five concentrations ranging from 1 to $10 \mu \mathrm{g} \cdot \mathrm{kg}^{-1}$. Portions of $25 \mathrm{~g}$ were taken for extraction adding $100 \mathrm{~mL}$ acetonitrile/water (80:20 v/v) to the sample, which was then mixed for 2 hours and filtered. To define the recoveries of the method, five points were used to build an analytical curve in order to obtain the $R$ values with replicates $(\mathrm{n}=3)$ in each point, corresponding to a mean of five spots, of each extract. The recoveries for $B_{1} ; B_{2} ; G_{1}$; and $G_{2}$, were $95,85,95$, and $85 \%$ respectively;

c) Mc: the mc analysis was carried out using the gravimetric method (ASSOCIATION OF OFFICIAL ANALYTICAL CHEMISTS, 2005);

d) Mycological tests: progressive dilutions were prepared and $0.1 \mathrm{~mL}$ of each was spread onto the agar on sterile Petri dishes. Plates were kept at $25^{\circ} \mathrm{C}$ for 5 days and the colonies of filamentous fungi and yeast were counted, isolated, and identified up to genera using Samson, Hoekstra and Frisvad (1999) methodology. The toxigenic strains of Aspergillus were identified up to species according Machida and Saito (1999); and

e) Statistics: to verify the occurrence of aflatoxin and the fungi presence, the descriptive statistic was used to obtain the simple frequency of variable occurrence, with $\mathrm{p}=5.0 \%$. 


\section{Results and discussion}

Despite of the contamination associated with the Brazil nut international trade, the results confirm the low number of contaminated samples but the high heterogeneity of the aflatoxin. This variability was observed in the same harvest, from the same origin (stage), and is corroborated by the findings of De Mello and Scussel (2007). This condition is important to reinforce the necessity of quality control and decrease the risk of aflatoxin.

\subsection{Association between aflatoxin and $m c$}

From the 120 analyzed samples, the aflatoxins were detected only in the 2003 and 2004 harvests. In those harvests, 9 samples $(7.5 \%)$ were contaminated with aflatoxin at the LOQ (1.95 $\mu \mathrm{g} . \mathrm{kg}^{-1}$ total aflatoxin) described as: At receiving, 4 (6.6\%); at the after drying stage $0(0.0 \%)$ and at the retail: $5(16.7 \%)$ (Table 1$)$. Concerning the contamination levels, only $2(3.3 \%)$ receiving and $3(10 \%)$ retail samples were above the limits for total aflatoxin established by Brazilian legislation $\left(30 \mu \mathrm{g} . \mathrm{kg}^{-1}\right)$. Considering the EU regulation, all 9 samples would be rejected to export because they exceed the limit of $4.0 \mu \mathrm{g} \cdot \mathrm{kg}^{-1}$. On the other hand, the Brazil nuts rejected to export can be commercialized in Brazil or in other markets with higher tolerance to aflatoxin limits. That is one of the reasons of the increase in the commercial relationship between Brazil nut factories and the US, Canada, China, Australia, and Vietnam that has happened since 1998. To prevent aflatoxin contamination, it is important to emphasize that the consumers have the ability to discard the apparent damaged nuts (MARKLINDER et al., 2005).

With regard to the stages, as expected, the samples (in-shell) at the receiving stage presented the highest levels of aflatoxin contamination compared to the after drying stage, in which no contamination below the LOQ was detected. That was probably due to the uncontrolled environmental conditions of Brazil nuts transport prior to the factory process. They are transported by ships in long rivers and long trips (over 30 days) with no temperature or relative humidity ( $\mathrm{rh}$ ) control, mostly. In the case of the retail samples $(n=5)$, the contamination $\left(\mathrm{X}=271.7 \mu \mathrm{g} \cdot \mathrm{kg}^{-1}\right.$ total aflatoxin) reinforce the need to control the procedures during storage and packaging to decrease the risk of aflatoxin contamination.

In the 2005 and 2006 harvests, the aflatoxins were not detected in the samples analyzed. That the can be explained due to the improvements made by the factories in process technology such as: educating the native communities, use good procedures in the collection, improvements in the storage, transportation, and new equipment for drying. All those factors were applied in association with more restrictive quality control procedures, hazard analysis, and critical control points (HACCP). The improvements have also been presented in the retail products including new packaging, with modified atmosphere, and storage control. These improvements were not applied during the 2003 and 2004 harvests. In other studies in which contamination was not detected in the samples, the origin and the number of samples became limiting factors to compare the results, such as the Kershaw (1985) with only one sample.

With regard to the mc content, as expected, the results were higher for the samples at the receiving stage, with mean of $22.43 \%$ (minimum $=11.2 \%$ and maximum $=31.5 \%$ ). At that stage, high levels of aflatoxin contamination were found. The comparison among mc means indicates the highest $\mathrm{mc}$ at the receiving stage and presented significant difference from the two other stage processes, but those did not present significant difference, as shown in Table 1. About 45 samples (37.5\%) were above the mc limit for commercialization (15\%) (BRASIL, 2004), but it is it can be noted that with an efficient drying process it is possible to decrease the mc of the nuts. The mc mean at the factory reception revealed that inadequate conditions of shipment and storage of Brazil nuts were affected by the tropical areas natural factors such as rain and high temperatures. Those factors could provide conditions to fungi metabolism produce aflatoxin. For the analyses presented in Table 1, the Fischer test indicate significant statistic only to the association of aflatoxin with $\mathrm{mc}$ levels in the factory receiving $(\mathrm{p}=0.045)$.

\subsection{Association between aflatoxin and isolated strains}

Some fungi strains, such as Aspergillus sp., Fusarium sp. and Penicillium sp. are considered native to the Brazil nut mycoflora and were observed in the samples. The most common strains were: A. flavus, A. niger, Absidia sp., Chalara sp., Fusarium sp., Gliocadium sp., Syncephalostrum sp. and Penicillum sp. (Table 2). The tests for the association between the strains indicated that Chalara sp. and Syncephalostrum sp. was not significant. Nevertheless, to the other strains, the highest incidence was in the retail samples. In the receiving samples, the Fusarium sp. emphasizes the presence of the remaining strains of the Brazil nut collection and storage in the forest. These conditions are frequent in tropical conditions of the Brazil nut trees, where Fusarium strains were previously reported by Cartaxo et al. (2004). In the case of the other strains, the temperatures of drying probably affected their growth.

Table 1. Aflatoxin levels and mc of Brazil nut (Bertholletia excelsa H.B.K.) in three stages of the process chain.

\begin{tabular}{lccccccccc}
\hline \multirow{2}{*}{$\begin{array}{c}\text { Factory } \\
\text { stages }\end{array}$} & $\begin{array}{c}\text { Number of } \\
\text { samples }\end{array}$ & \multicolumn{3}{c}{ Aflatoxin $\left(\mu \mathrm{g} \cdot \mathrm{kg}^{-1}\right)^{\mathrm{a}}$} & \multicolumn{3}{c}{ Mc $(\%)$} \\
\cline { 3 - 9 } & & $\begin{array}{c}\mathrm{N}^{\mathrm{a}} \text { of positive } \\
\text { samples }(\%)\end{array}$ & Mean & Range & RSD \% & $>15 \%^{\mathrm{b}}$ & Mean & Range & RSD \% \\
\hline Receiving & 60 & $4(6.7 \%)$ & 46 & $10-68$ & 1.3 & 45 & $22.43^{\mathrm{d}}$ & $11.2-31.5$ \\
After drying & 30 & $0(\%)$ & $\mathrm{ND}^{\mathrm{c}}$ & $\mathrm{ND}$ & $\mathrm{ND}$ & 0 & $3.26^{\mathrm{e}}$ & $1.8-6.4$ & 0.9 \\
Retail $^{\mathrm{f}}$ & 30 & $5(16.7 \%)$ & 271.7 & $8-686$ & 9.9 & 5 & $2.92^{\mathrm{e}}$ & $11.5-22.5$ & 0.6 \\
\hline
\end{tabular}

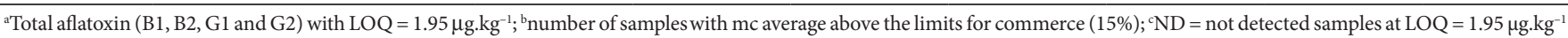
total aflatoxin; ${ }^{\mathrm{d}, ~ e} \mathrm{mc}$ mean followed by distinct letters are different at the significant level of $5.0 \%$; ${ }^{\mathrm{f}}$ retail samples could be the discarded ones along the process to export, and commercialized into the national food industry. 
The retail samples presented the majority of strains found in the other stages, exception for Chalara sp., Fusarium and Gliocadium sp. In those samples, A. flavus was frequent (63\%) and this result corroborates the findings of Freire, Kozakiewicz and Paterson (2000) that analyzed Brazil nuts supplied by similar precedence (retail). The A. flavus presented the highest percentage of infection on the surface of Brazil nuts (27.5\%), followed by Penicillium glabrum (21.5\%) and Rhizopus oryzae (15.8\%). The A. flavus and Penicillium sp. strains were present in all stages. A significant difference in the association between $A$. flavus and $A$. niger species was detected in terms of the presence of potential aflatoxigenic strains and aflatoxin, despite the fact that niger was detected only in the retail samples. It is important to emphasize that in unprocessed nuts collected from the forest by Cartaxo et al. (2004), those were the predominant strains. In the case of Brazil nut pods collected from the forest by Arrus et al. (2005b), the Aspergillus, Penicillium and Fusarium were also detected. Their presence indicated those as an original contamination, and not only associated with inadequate storage at the markets, observed in the retail samples. The Fischer test indicates statistical significance for the association of aflatoxin presence, the A. flavus ( $\mathrm{p}=0.0001)$, and A. Niger $(\mathrm{p}=0.027)$ strains (Table 3).

Table 2. Aflatoxigenic strains in three stages of the Brazil nut (Bertholletia excelsa H.B.K) process chain.

\begin{tabular}{|c|c|c|c|c|c|}
\hline \multirow[t]{2}{*}{ Strains } & \multirow[t]{2}{*}{ Findings } & \multicolumn{3}{|c|}{ Process stages } & \multirow[t]{2}{*}{ p-value } \\
\hline & & Receiving & After drying & Retail & \\
\hline \multirow{2}{*}{ A. flavus } & Absent & $57(95.0 \%)$ & $28(93.33 \%)$ & $19(63.33 \%)$ & \multirow{2}{*}{0.001} \\
\hline & Present & $3(5.0 \%)$ & $2(6.67 \%)$ & $11(36.67 \%)$ & \\
\hline \multirow{2}{*}{ A. niger } & Absent & $60(100.0 \%)$ & $30(100.0 \%)$ & $20(66.67 \%)$ & \multirow{2}{*}{0.001} \\
\hline & Present & $0(0.0 \%)$ & $0(0.0 \%)$ & $10(33.33 \%)$ & \\
\hline \multirow{2}{*}{ Yeasts } & Absent & $58(96.67 \%)$ & $6(20.0 \%)$ & $29(96.67 \%)$ & \multirow{2}{*}{0.001} \\
\hline & Present & $2(3.33 \%)$ & $24(80.0 \%)$ & $1(3.33 \%)$ & \\
\hline \multirow{2}{*}{ Penicillium sp. } & Absent & $45(75.0 \%)$ & $26(86.67 \%)$ & $6(20.0 \%)$ & \multirow{2}{*}{0.001} \\
\hline & Present & $15(25.0 \%)$ & $4(13.33 \%)$ & $24(80.0 \%)$ & \\
\hline \multirow{2}{*}{ Fusarium sp. } & Absent & $45(75.0 \%)$ & $29(96.67 \%)$ & $30(100.0 \%)$ & \multirow{2}{*}{0.001} \\
\hline & Present & $15(25.0 \%)$ & $1(3.33 \%)$ & $0(0.0 \%)$ & \\
\hline \multirow{2}{*}{ Gliocadium sp. } & Absent & $54(90.0 \%)$ & $30(100.0 \%)$ & $30(100.0 \%)$ & \multirow{2}{*}{0.013} \\
\hline & Present & $6(10.0 \%)$ & $0(0.0 \%)$ & $0(0.0 \%)$ & \\
\hline \multirow{2}{*}{ Chalara sp. } & Absent & $59(98.33 \%)$ & $30(100.0 \%)$ & $30(100.0 \%)$ & \multirow{2}{*}{0.498} \\
\hline & Present & $1(1.67 \%)$ & $0(0.0 \%)$ & $0(0.0 \%)$ & \\
\hline \multirow{2}{*}{ Syncephalostrum sp. } & Absent & $60(100.0 \%)$ & $30(100.0 \%)$ & $28(93.33 \%)$ & \multirow{2}{*}{0.059} \\
\hline & Present & $0(0.0 \%)$ & $0(0.0 \%)$ & $2(6.67 \%)$ & \\
\hline \multirow{2}{*}{ Absidia sp. } & Absent & $60(100.0 \%)$ & $30(100.0 \%)$ & $26(87.67 \%)$ & \multirow{2}{*}{0.003} \\
\hline & Present & $0(0.0 \%)$ & $0(0.0 \%)$ & $4(13.33 \%)$ & \\
\hline
\end{tabular}

${ }^{a} \mathrm{p}<0.05$ indicates statistic significant.

Table 3. Relation between the aflatoxin presence and isolated fungi from Brazil nut (Bertholletia excelsa) samples.

\begin{tabular}{|c|c|c|c|c|}
\hline \multirow[t]{2}{*}{ Strains } & \multirow[t]{2}{*}{ Findings } & \multicolumn{3}{|c|}{ Aflatoxins (\%) } \\
\hline & & Absent & Present & p-value \\
\hline \multirow{2}{*}{ A. flavus } & Absent & $100(90.1 \%)$ & $11(9.9 \%)$ & \multirow{2}{*}{0.0001} \\
\hline & Present & $4(44.5 \%)$ & $5(55.7 \%)$ & \\
\hline \multirow{2}{*}{ A. niger } & Absent & $104(93.7 \%)$ & $7(6.3 \%)$ & \multirow{2}{*}{0.027} \\
\hline & Present & $6(66.7 \%)$ & $3(33.4 \%)$ & \\
\hline \multirow{2}{*}{ Yeasts } & Absent & $84(75.7 \%)$ & $27(24.3 \%)$ & \multirow{2}{*}{0.206} \\
\hline & Present & $9(100.0 \%)$ & $0(0.0 \%)$ & \\
\hline \multirow{2}{*}{ Penicillium sp. } & Absent & $73(65.8 \%)$ & $38(34.3 \%)$ & \multirow{2}{*}{0.279} \\
\hline & Present & $4(44.5 \%)$ & $5(55.6 \%)$ & \\
\hline \multirow{2}{*}{ Fusarium sp. } & Absent & $97(87.4 \%)$ & $14(12.6 \%)$ & \multirow{2}{*}{0.343} \\
\hline & Present & $7(77.8 \%)$ & $2(22.3 \%)$ & \\
\hline \multirow{2}{*}{ Gliocadium sp. } & Absent & $105(94.6 \%)$ & $6(5.4 \%)$ & \multirow{2}{*}{1.00} \\
\hline & Present & $9(100.0 \%)$ & $0(0.0 \%)$ & \\
\hline \multirow{2}{*}{ Chalara sp. } & Absent & $110(99.1 \%)$ & $1(0.9 \%)$ & \multirow{2}{*}{1.00} \\
\hline & Present & $9(100.0 \%)$ & $0(0.0 \%)$ & \\
\hline \multirow{2}{*}{ Syncephalostrum sp. } & Absent & $110(99.1 \%)$ & $1(0.90 \%)$ & \multirow{2}{*}{0.145} \\
\hline & Present & $8(88.9 \%)$ & $1(11.1 \%)$ & \\
\hline \multirow{2}{*}{ Absidia sp. } & Absent & $107(96.4 \%)$ & $4(3.6 \%)$ & \multirow{2}{*}{1.00} \\
\hline & Present & $9(100.0 \%)$ & $0(0.0 \%)$ & \\
\hline
\end{tabular}

${ }^{\mathrm{a}} \mathrm{p}<0.05$ indicates statistic significant. 


\section{Conclusions}

Aflatoxin is present in the Brazil nut chain despite the contamination heterogeneity with statistical association between the moisture content and the aflatoxin production with the aflatoxigenic fungi. These findings show the necessity of controlling environmental factors such as the rh, temperature, and the use of the good practices at the collection areas and in the factory process to avoid fungi contamination and to guarantee the safety of the nuts. The results can be useful to help the institutional and government programs that have been applied to improve the Brazil nut quality (BRASIL, 2004; CODEX ALIMENTARIUS, 2006). The study of the mc relation with water activity and continuous identification of fungi strains can provide information to develop mechanisms of decontamination. These are aspects to be explored, as well as the antioxidant role of the Brazil nut composition, and its influence on the fungi metabolism. The Brazil nuts safety, with controlled contamination of aflatoxin, could remove the possibility of wastes, avoid commercial barriers, keep the Brazil nut area and reinforce the importance of the rain forest products.

\section{Acknowledgments}

The authors are grateful to the technicians of the Nutricon laboratory.

\section{References}

ANDRADE, E. H. A. et al. Seed composition of Amazonian Lecythidaceae Species: Part 3 in the Series "Studies of Edible Amazonian Plants". Journal of Food Compositon and Analysis, v. 12, p. 37-51, 1999.

ASSOCIATION OF OFFICIAL ANALYTICAL CHEMISTS - AOAC. Official Methods of Analysis of AOAC International. $18^{\text {th }}$. HORWITZ, W. and LATIMER Jr., G. W. (Eds.). Gaithersburg, Maryland, USA, 2005.

ARRUS, K. et al. Aflatoxin production by Aspergillus flavus in Brazil nuts. Journal of Stored Products Research, v. 41, n. 5, p. 513-527, 2005a.

ARRUS, K. et al. Microbiological and aflatoxin evaluation of Brazil nut pods and the effects of unit processing operations. Journal of Food Protection, v. 68, n. 5, p. 1060-1065, 2005b.

BAYMAN, P.; BAKER, J.; MAHONEY, N. Aspergillus on tree nuts. Mycopathologia, v. 155, p. 161-169, 2002.

BRASIL. Ministério da Agricultura, Pecuária e Abastecimento. Monitoramento e segurança na qualidade da Castanha do Brasil e da cadeia produtiva. Diário Oficial da União, Brasília, 28 de maio de 2004, Seção 1, p. 24.

CALDAS, E.; SILVA, S. C.; OLIVEIRA, J. N. Aflatoxins and ochratoxin A in food and the risks to human health. Revista de Saúde Pública, v. 36, n. 3, p. 319-323, 2002.

CANDLISH, A. A. G. et al. A survey of ethic foods for microbial quality and aflatoxin content. Food Additives and Contaminants, v. 18, n. 2, p. 129-136, 2001.

CARTAXO, C. et al. Occurrence of aflatoxin and filamentous fungi contamination in Brazil-nuts left inside the forest. In: SEMINAR CIENTIA INTERNATIONAL DE SALUD ANIMAL, Havana, CU, 2004. Abstracts...

CASTRILLON, A. L.; PURCHIO, A. Contaminating fungi producing aflatoxins in Brazil nuts (Bertholletia excelsa Humb. \& Bonpl 1808). Acta Amazonica, v. 18, n. 3, p. 173-183, 1988.
CHANG, J. C. et al. Selenium level of Brazil nuts from two geographic locations in Brazil. Chemosphere, v. 30, n. 4, p. 801-802, 1995.

CODEX ALIMENTARIUS. Code of practice for the prevention and reduction of aflatoxin contamination in tree nuts. Netherlands, 2006. (CAC/RCP 59-2005).

De MELLO, F. R.; SCUSSEL V. M. Characteristic of in-shell Brazil nuts and their relationship to aflatoxin contamination: criteria for sorting. Journal of Agricultural and Food Chemistry, v. 55, n. 22, p. 93059310, October 2007.

EUROPEAN UNION - EU. Commission Regulation 1525/98 of 16 July 1998, amending Regulation (EC) N. 194/97 of January 1997 setting maximum levels for certain contaminants in foodstuff. Official Journal of European Communities, 1998a.

EUROPEAN UNION - EU. Commission Directive 98/53/EC of 16 July 1998, laying down the sampling methods and the methods of analysis for the official control of the levels for certain contaminants in foodstuff. Official Journal of European Communities, 17 de julho de 1998, L 201/93, 1998b.

FREIRE, F. C. O.; KOZAKIEWICZ, Z.; PATERSON, R. M. Mycoflora and mycotoxins in Brazilian black pepper, white pepper and Brazil nuts. Mycopathologia, n. 149, p. 13-19, 2000.

INTERNATIONAL AGENCY OF RESEARCH ON CANCER - IARC. Evaluation of carcinogenic risks to humans: some naturally occurring substances: aromatic amines and mycotoxins. In: IARC Monographs. Lyon, 1997. p. 245-395.

INSTITUTO BRASILEIRO DE GEOGRAFIA E ESTATÍSTICA - IBGE Produção da Extração Vegetal e Silvicultura 2002. Disponível em: $<$ http://www.ibge.gov.br>. Acesso em: 11 mar. 2005.

IOANNOU-KAKOURI, E. et al. Surveillance and Control of Aflatoxins B1, B2, G1, G2 and M1 foodstuffs in the Republic of Cyprus: 1992-1996. Journal of AOAC International, v. 82, n. 4, p. 883-892, 1999.

KERSHAW, S. J. Aflatoxins in imported edible nuts: some data 1982-84. Journal of Food Technology, v. 20, p. 647-649, 1985.

MACHIDA, S.; SAITO, M. A Rapid identification method for producing strains of Aspergillus flavus and A. parasiticus by ammonia vapor. Mycoscience, v. 40, p. 205-208, 1999.

MARKLINDER, I. et al. Consumer's ability to discriminate aflatoxincontaminated Brazil nuts. Food Additives and Contaminants, v. 22 , n. 1, p. 56-64, 2005.

PACHECO, A. M.; SCUSSEL, V. M. Brazil Nut: From Tropical Forest to Consumer. Florianopolis, SC: Editograf, 2006.

PACHECO, A. M.; SCUSSEL, V. M. Selenium and Aflatoxin levels in raw Brazil nuts from the Amazon basin. Journal of Agricultural and Food Chemistry, v. 55, n. 26, p. 11087-11092, 2007.

PITT, J. I. Fungal ecology and the occurrence of mycotoxin. Mycotoxins and phycotoxins: advances in determination, toxicology and exposure management. In: INTERNATIONAL SYMPOSIUM ON MYCOTOXINS AND PHYCOTOXINS - IUPAC, 11, 2004, Bethesda, Maryland, 2006. Proceedings... p. 33-41.

RYAN, E. et al. Fatty acid pro file, tocopherol, squalene and phytosterol content of Brazil, pecan, pine, pistachio and cashew nuts. International Journal of Food Sciences and Nutrition, v. 57, p. 219-228, 2006.

SAMSON, R. A.; HOEKSTRA, E. S.; FRISVAD, J. C. Introduction to food and Airborne Fungi. 7 ed. The Netherlands: Easternbureau voor Schimmelcultures, 2004. 389 p.

STEINER, W. E. et al. Aflatoxins and fluorescence in Brazil nuts and Pistachio nuts. Journal of Agricultural and Food Chemistry, v. 40, n. 12, p. 2453-2457, 1992.

THUVANDER, A. et al. Dietary intake of some important mycotoxins by the Swedish population. Food Additives and Contaminants, v. 18, n. 8 , p. $696-706,2001$. 